\title{
The German Attack on the Witboois at Hornkranz, Namibia, April 1893
}

\author{
Piet van Rooyen ${ }^{275}$ \\ Professor emeritus, School of Military Science, University of Namibia
}

\begin{abstract}
For many, when the Namibian struggle for liberation is mentioned, the struggle for liberation by the South West Africa People's Organization (SWAPO) comes to mind. For others to the south of Namibia, it recalls images of a border war and incursions into Angola to 'stop SWAPO', the latter seen as a communist pawn directed and armed by the Soviet Union and Cuba. More than that is seldom asked about or seen in terms of the bigger historical collage. The brutal era of German colonisation is habitually overlooked. The Namibians' struggle for liberation lasted nearly a century. It started through, for example, the massacre or battle, depending on your view, in April 1893. This previously poorly researched story about which little is written is told in this article.
\end{abstract}

Keywords: Namibia (liberation struggle), German colonisation, Hendrik Witbooi, Hornkranz (the battle of), German West Africa, Witboois, arms traders (in Namibia/ German West Africa, 1880s).

\section{Introduction}

The Khomas Hochland (Khomas Highland) of Namibia offers a unique geological substratum of rocky hills and dense savanna-type thorn bush. The land surface lies strewn with quartzite rocks and mica schist. ${ }^{276}$ In the valleys between the rocky outcrops run perennial rivers, the banks of which are thickly overgrown with riverine trees. Here and there, fountains erupt from the sand, releasing rainwater to the surface where people and animals gathered and still gather to drink and live. Before the sinking of boreholes by drilling machines started in the early 1900s, these fountains were the only sources of water for much of the year. One such water source was Hornkranz (also spelled Hornkrantz or Hoornkrans) where early San inhabitants of Namibia made their temporary hunting camps and where Hendrik Witbooi, the Orlam/Nama leader settled in the latter half of the 1800 s. It is here that this narrative starts.

Near the cattle enclosure on the southern side of the main farmhouse and right next to the farmhouse, two separate memorial stones were erected by the Nama nation to commemorate the legendary Witbooi warrior, Captain Hendrik Witbooi, the man whose face still appears on Namibian dollar (ND) notes today. Witbooi was a sworn enemy of the German occupying forces in Namibia in the late 1800s. He had his home base at Hornkranz, where there was sufficient water in the Gaub River to sustain his people and his livestock, and from where he could raid his neighbours in Namaland to the south and Hereroland to the north. ${ }^{277}$ 
In retaliation for his reluctance to subjugate himself to German domination, German troops under the command of Captain Curt von Francois attacked Hendrik Witbooi's settlement in the early hours of 12 April 1893 at Hornkranz. Although the numbers of soldiers taking part in the attack are not mentioned in any of the sources, the total number of Schutztruppe in the German garrison in Windhoek consisted of 250 soldiers. ${ }^{278}$

The first shots were fired at first light. Eventually, 88 Witboois were killed by Schutztruppe fire. The deceased were mostly old men, women and children. Witbooi and the vast majority of his warriors came away unharmed. As indicated by the four gravestones at the site, one German soldier, 23-year-old corporal W Sakolowski, died in the attack. Another three soldiers died in later months from circumstances unrelated to the battle, while stationed at the site. ${ }^{279}$

\section{Methodology}

The methodological approach for this study comprised the following elements: descriptive, exploratory and qualitative. In terms of the descriptive approach, the use of documentation from local and other archives was crucial, especially on German colonialism and the life and times of Hendrik Witbooi and the Orlam people. In addition, several secondary sources, including chapters from books, edited books, articles and monographs, were used. Additional materials were sourced from relevant publications applicable to the topic.

The exploratory element was appropriate, as no prior in-depth study had been undertaken about the 1893 raid on Hornkranz. As an event, the Hornkranz attack is of such historical importance that it deserves investigation. The study discussed here attempted to open the way for more systematic research in the future. The life and death of Witbooi - and especially the raid on Hornkranz - stand central in understanding the Namibian (armed) struggle for independence. The author trusts that the current study about the events at Hornkranz on that morning will spur further studies regarding the issue on a systematic basis.

In a qualitative research approach, 'on-the-ground' data gathered by the researcher are crucial. In order to gain more data, the physical exploration of the area where the raid took place, was of great value and had to be part of the research plan. Several trips were made to the immediate area at Hornkranz as well as the surrounding areas where the Witbooi people built small fortified defence positions and lookouts (ramparts). A thorough combing of the area, mapping of the area, and acquainting oneself with the research setting in order to try and understand the angles of attack and the immediate developments there, played a crucial role in data collection and added much detail. The gathering of materials, such as spent ammunition cases and identifying these played a pivotal role in such an approach. The area was visited and re-visited, and objects like food cans, drinking vessels, and spent cartridge cases were physically searched for and retrieved after more than a hundred years, in order to make an analysis of the cultural background and the weaponry used by the conflicting parties. 
It was imperative that the author had to be conversant with arms and ammunition of the time as well as with the historical setting. Historical background knowledge about colonialism, especially German colonialism, was necessary. So was the need to have some insight in the larger European politics of the time (Grosse Politik), i.e. the Berlin Conference, colonialisation politics and knowledge of the socio-historical elements of people that populated the area before the advent of German colonialism. In this sense, knowledge of South West Africa (previously German South West Africa, today Namibia) was a requirement.

\section{Reasons for the attack at Hornkranz}

Two main factors lie at the origin of the attack: the growing German interest in South West Africa (now Namibia); and the regular raids on other indigenous groups, bolstered by horses and modern rifles, by the Orlam Nama, of which the Witboois were part.

The Orlam Nama originated from the British-ruled Cape Colony, where they gained experience in horse breeding and the use of horses and rifles in hunting and in commandotype campaigns and raids on 'hostile' neighbours. Rifles and ammunition were made available by travelling traders in exchange for cattle, ivory and ostrich feathers. These weapons the Orlam (a term derived from the Malay word 'orang lama', meaning a wise man) quickly learned to use with deadly effect against their more traditionally armed ethnic compatriots in Southern Africa. The commando system of raids (mostly for cattle and small stock) eventually drove the Orlam Nama deeper and deeper into the interior of Southern Africa, from where some groups, including the Afrikaanders and the Witboois, in the early 1800s, eventually crossed the Orange (Gariep) River into what is now Namibia. Here they attacked the indigenous people in a relentless series of hit-and-run raids. ${ }^{280}$

An Orlam Nama commando usually consisted of ten to fifty armed men on horseback, although sometimes many more riders took part in a foray. Jonker Afrikaner's commando to the then Ovamboland in 1852 comprised of at least 200 men. ${ }^{281}$

The objectives of the commando were at once political and economic. The objectives originated in both the indigenous and colonial systems, using indigenous alliances in corroboration with colonially gained military experience, horses and weaponry. Raids on weaker neighbouring groups took place regularly. The missionary Joseph Tindall recorded at least one raid per year by the Orlam group led by Amraal Lamberts, stationed at Naosanabis, on the Nossob River, near the current Leonardville, between 1848 and 1851. The Bethanie Orlam executed several raids a year on neighbouring groups. Qellen reports 15 raids a year executed by the Kai//Khaun in $1851 .{ }^{282}$

A keen knowledge of the local terrain, together with the instinct of primitive hunters and a ruthless attitude towards enemies made them a highly feared and efficient military or renegade force in the mid-1800s in Southern Africa. The depletion of targeted cattle herds and the dispersion of targeted local inhabitants led to the migration of these commando groups deeper into the interior of Southern Africa. Jonker Afrikaner and his 
people were the first of these semi-westernised commando groups to cross the border into Southwest Africa (now Namibia), soon followed by others, including the Witboois under Kido Witbooi, Hendrik Witbooi's grandfather. ${ }^{283}$

It was the time of " the scramble for Africa", and Germany, like other European nations, such as Great Britain, Belgium, France and Spain, played a role. Germany made more and more inroads into South West Africa, firstly through traders and prospectors, and then by means of a military contingent of protection troops, the socalled Schutztruppe. These soldiers were first mobilised in order to protect German interests in South West Africa, but concomitant with these interests, and as a contingent measure with the same objective, to "protect" (schutz) other indigenous inhabitants from the raids by the Orlam and other hostile groups, it was argued. ${ }^{284}$

The German military command in German South West Africa generally therefore perceived their military actions against the raider groups as justified, whatever the means. The Witboois at Hornkranz were viewed through the same lens.

\section{Colonial background}

As part of the rush for colonial expansion, many major European powers annexed large areas of Africa and other parts of the underdeveloped (non-industrialised) world in the 1880s. Germany, who had no overseas possessions at that stage, decided to do the same. The intricacies of the political economy of a country under the influence of rapid industrialisation and a concomitant rise in unemployment, made the German government consider colonisation as a project to unify the nation and to distract attention from the difficulties of the national economy. Colonisation would raise the international status of Germany, find markets for manufactured goods, and provide employment to young German citizens as colonial officials, police officers and soldiers.

At the conference held by the major European states in Berlin from 1884 to 1885, the European powers agreed on the legal basis of their occupation and partition of Africa. By the end of that decade, Germany had established colonies in the Cameroons, Togoland, East Africa and South West Africa. By that time, traders, such as Adolf Lüderitz, had already bought vast tracts of land from the native chiefs in South West Africa, which gave the German government the basis on which to install and expand German authority in the country. The indigenous leaders soon used the German influence to bolster their own interest in the existing power struggles between the raiders and the raided.

Taking advantage of the internal struggles, agents of the German government negotiated protection treaties with the local inhabitants, thereby gaining a foothold for further German occupation. Generally speaking, these agreements guaranteed the security of the German traders and their families and prevented indigenous groups from seeking alliances with other European powers. In this way, between 1884 and 1885 , most of the people of central and southern Namibia had been drawn into formal relations with the German government by means of these protection treaties. ${ }^{285}$ 
Some of the Nama/Orlam groups, including the Witboois, however, refused to sign these 'protection treaties', because this would have restricted their freedom to proceed with the usual commando activities against their neighbours.

Although the German government sent warships to the South West African coast as early as 1884 in order to protect the interests of German traders dependent on shipping for their trade, official German presence in the interior of the country remained marginal. With the Imperial Commissioner, Hermann Göring, there were only his secretary and a police superintendent as government officials. With the escalation of inter-ethnic violence, the German government decided to send a military presence to the colony. In 1888 , the first German soldiers arrived in South West Africa. ${ }^{286}$

While Germany was increasing its sphere of influence in the country, Hendrik Witbooi and his soldiers were gaining increasing dominance in southern and central South West Africa. Through a series of well-executed military campaigns, Hendrik Witbooi established dominance over rival Orlam/Nama groups like the Rooinasie, the Grootdoden, the Veldschoendragers and the Afrikaanders. He and his mounted soldiers won decisive battles against the Herero. Many of these groups were already under the legal protection of Germany. ${ }^{287}$

The details of the establishment and consolidation of Hendrik Witbooi's military and - to an extent - political successes have not been fully analysed in previous studies. It is clear that he was able to amass wealth and a following through the successful raiding of cattle and small stock. The raided cattle were exchanged for rifles and ammunition from traders, not only within the territory of South West Africa, but as far away as Walvis Bay and Cape Town.

\section{Hendrik Witbooi as military leader}

Witbooi had remarkable personal charisma, which impressed itself not only on his followers, but also on his enemies. The Herero called him Otjikorta ('the short one') and perceived him with fear and awe. After a revelation in the Auas Mountains, during which he saw a light and heard a voice, which told him to lead his people to greatness, Witbooi became not only a shrewd military leader, but also a religious leader and a prophet, which gave his military activities a sense of (pre)destination. In 1889, he established a base at Hornkranz, a hundred kilometres west of Rehoboth (120 kilometres southwest of Windhoek). He had with him several of his Witbooi followers from the Gibeon days but also many vagrants ('leaderless people') from other Nama and Orlam groups, such as the former followers of Jan Jonker Afrikaander, Arisemab and Paul Visser.

At Hornkranz, Witbooi established a tightly-knit Christian community, based on the economics of stock raiding, hunting and animal husbandry. Under his auspices, an effective military force was created, for which the breeding, trading and raiding of horses was a prerequisite. Rifles and ammunition were traded from the British traders, until such trade was banned by the resident German government. 
Witbooi's military power vis-à-vis that of the German contingent, was demonstrated at this time, when in September 1890, returning from a raiding expedition from Herero and Damara settlements, he demanded to water his horses and cattle at the German military base of Tsaobis, without the German commander having the troops to resist him. ${ }^{288}$

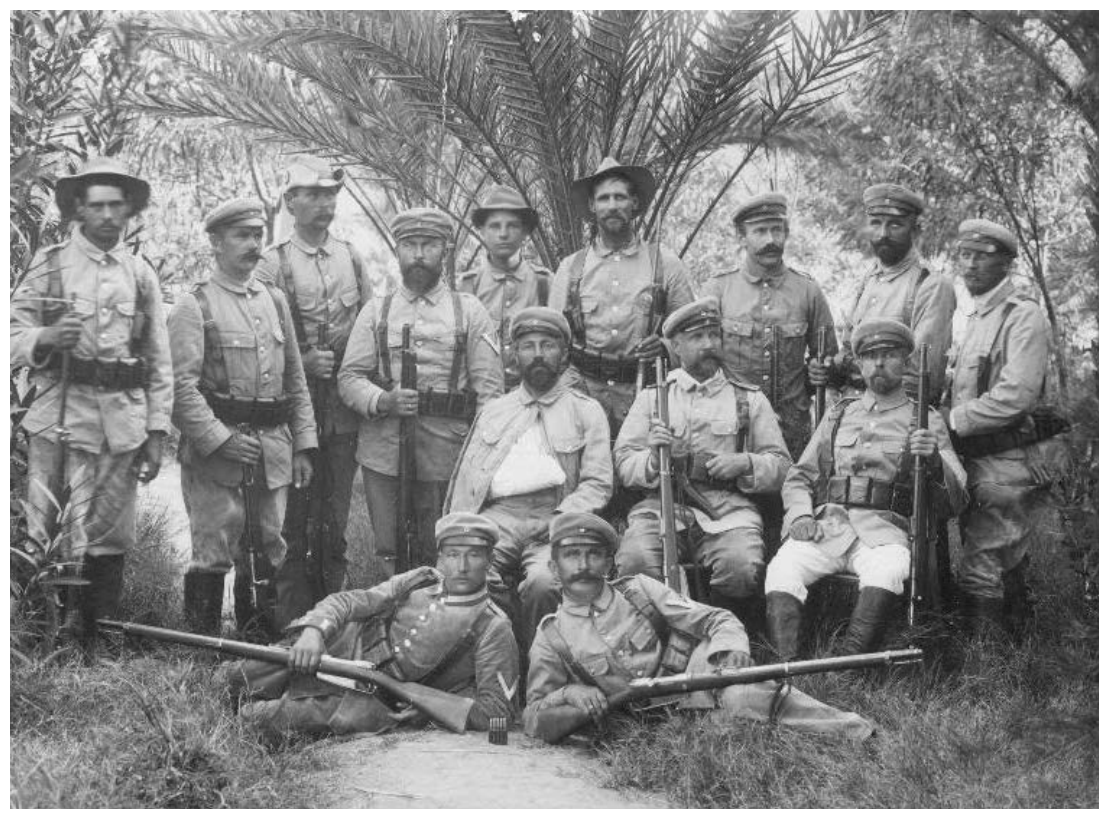

Figure 1: German Schutztruppe with 88 Mauser rifles in Windhoek. ${ }^{289}$

In his later report on the Hornkranz attack, Captain Curt von Francois, the German military commander in German South West Africa, describes his peace-making visit to Captain Witbooi at Hornkranz. Von Francois puts the blame for the killings on the reluctance of Witbooi to lay down arms and accept the German Protection Treaty, as other groups in the country had done. ${ }^{290}$

After the attack, Witbooi wrote a letter to the Baster captain, Hermanus van Wyk, in which he described the attack in the following manner: ${ }^{291}$

Captain von Francois attacked us early in the morning while we were sleeping unsuspectingly, and while I was trying to protect my people, we were unable to drive them back. The captain invaded the camp and ruined it in such a brutal way as I could never imagine a member of a civilized White nation capable of - a nation that knows the rules and ways of warfare. But this man robbed me, killing little children on their mothers' breasts, and older children and women and men. The bodies of the people killed were burned inside the 
grass huts, their bodies burnt to ashes. With pertinence and terribly harsh action Captain von Francois did his work, in a shameless operation.

As far as I am concerned, the Germans set fire to this whole country in order to crush the whole of Hereroland and Namaqualand, so as to possess our entire land, and to make us their subjects and their slaves. So, dear brother, get up, let us oppose the Germans for the cause of our country and our nations. It's an attack on us all. Come to my aid, dear brother, with weapons, such as guns, a keg of gunpowder, and Martini Henry shells and lead. As you know, the Germans stopped my arms supply, and now that I am unarmed, they attack me. Please let me hear from you soon.

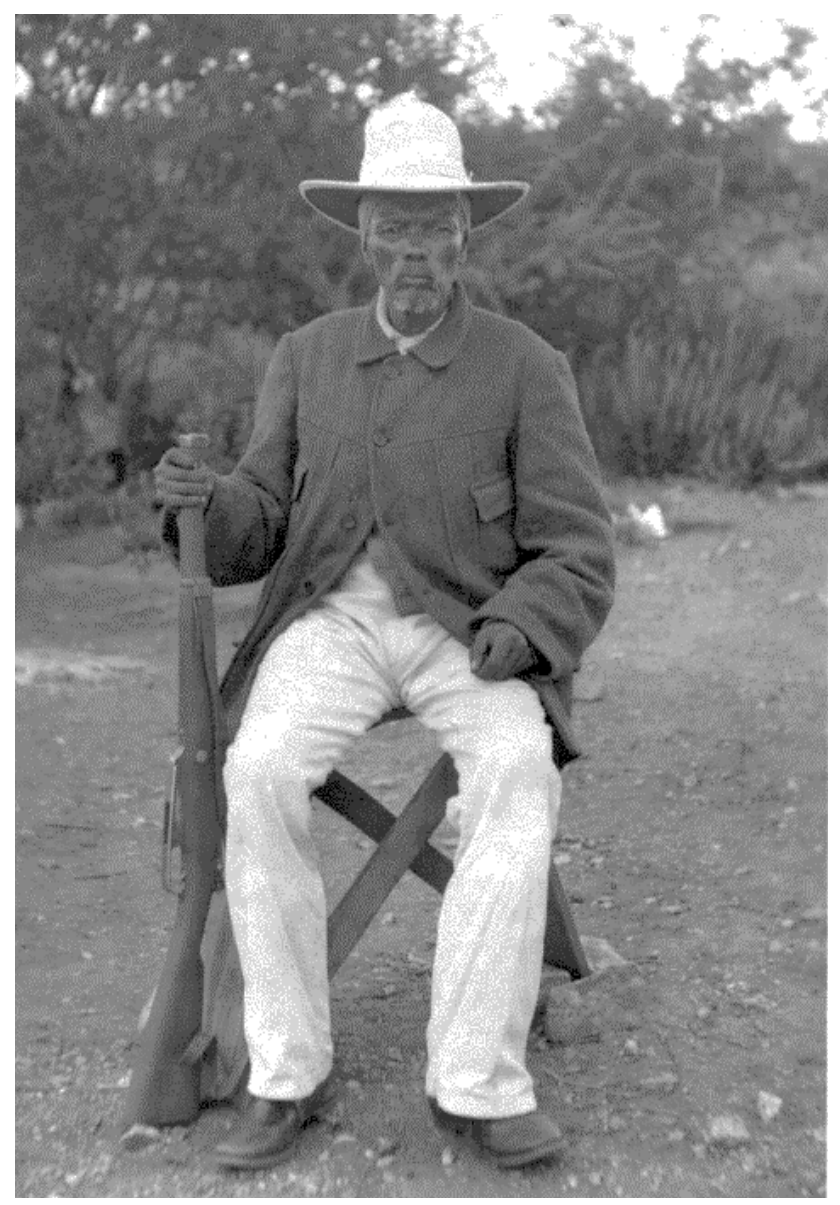

Figure 2: Hendrik Witbooi. ${ }^{292}$ 


\section{An early appeal for international intervention}

Witbooi's approach went further. In an appeal for help, Witbooi wrote to the English magistrate in Walvis Bay describing the attack in the following terms: ${ }^{293}$

\section{Dear Lord,}

I've already told you of my conflict with the Germans. Now I have to tell you about the big blow that the Germans inflicted on me. Captain von Francois launched a surprise attack on me on April 12, without a word, and without any mistake on my side. He did not even warn me beforehand.

Two of my elders went to Windhoek and came back with a note from the captain that he would soon be sending me a letter for a treaty. While I was still waiting for this letter, the captain moved in with his troops, without anyone knowing it, and he attacked early in the morning, before sunrise, while we were still sleeping. When we awoke, the troops was already inside our camp, and started firing all over the place. I had no proper ammunition with me, because I was not involved in a war, and because I was not expecting that kind of thing from the Germans. They always boasted about their great power of people and weapons, so I didn't expect such a powerful man - in addition to the ruling representative of the emperor of a civilized nation - to carry out such a cowardly raid against a small and unimportant person like me, as if he wanted to rob me - because they were actually sneaking in while we were still sleeping.

He destroyed my settlement and killed my people without distinction: small children, women, and men. He burned the dead bodies of some of the people he shot. He took some of the women away. That is how brutally the captain dealt with my camp, as I would never expect from any White man.

He killed ten men, and 75 women and children, while I could not fight back, but had to flee with my people. Because, as you know, you have unanimously decided to stop my ammunition supply. That way, the Germans shed the blood of innocent women and children. And he said he wouldn't stop until he destroyed me.

So again, I report to you, dear Magistrate, as a friend, please tell the Cape Government urgently of these things. Let the Cape government call the German government accountable, to see if they are aware of this attack, and whether it has been done at their command. And if they do, and approve of it, then I plead with you, dear Magistrate, to allow Britain to open my arms supply, that I can defend myself. Because I can't think that such actions as the Germans have ever done can be seen as justified or proper or honest by any civilized power. First, the Germans stop my ammunition supply, and as soon as I can't defend myself, like a bull without horns, they attack me. According to me, it's murder, because I am as helpless as a woman. 
That's why I ask your mighty gentleman if you can't say anything to reject or stop this illegal and deliberate act of violence. Also, help me with weapons and ammunition in my desperate condition. Help me with Martini Henry ammunition. Open up the provision of firearms, because the Germans say they will play havoc with me and with all the captains in Namaqualand, as well as with the Herero.

The Germans set fire to the world without a cause. Please announce these terrible and sad events to all the leaders of Britain and Germany, and make it quick. Let them hear about this.

So much for the moment. I greet you courteously.

Your friend,

Hendrik Witbooi.

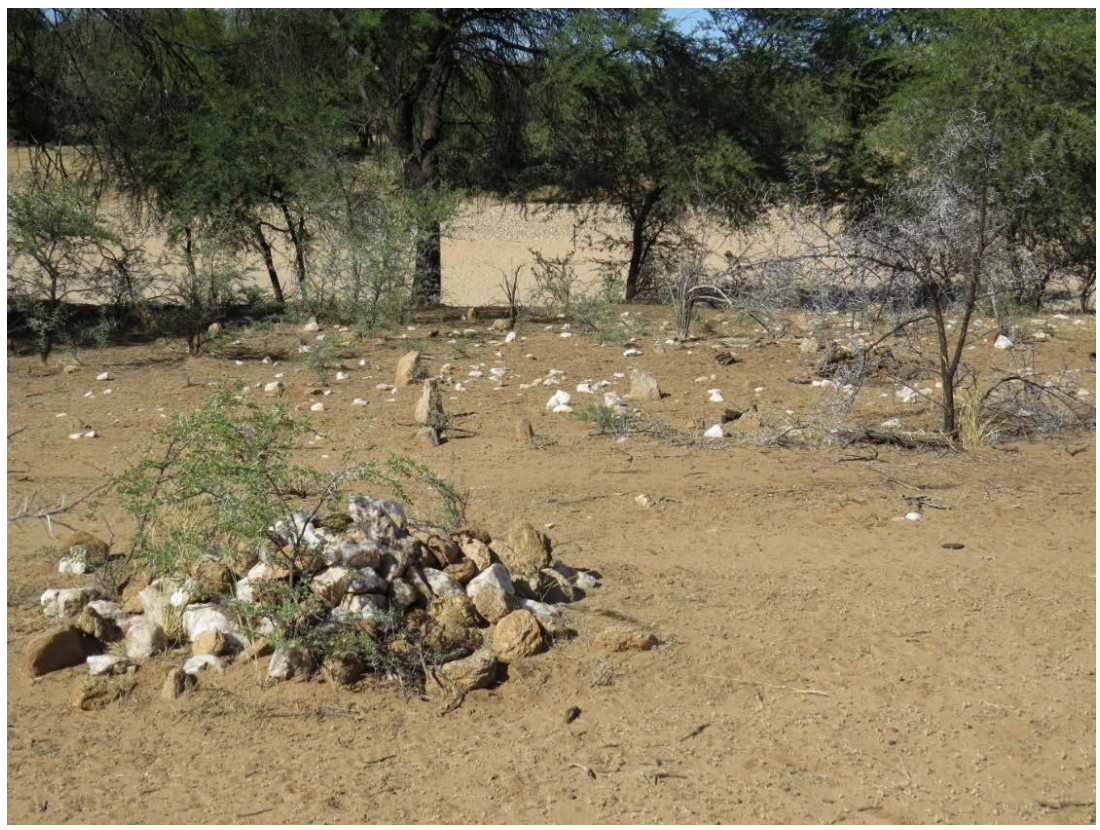

Figure 3: The Nama graves at the site of the attack. ${ }^{294}$

In writing this letter to the British authorities, Witbooi can be accredited for engaging in diplomacy with Britain and attempting to influence a great power. Hendrik Witbooi, astute as he was, was clearly aware of the tensions between Britain and the rising Germany and attempted to make full use of this in his interaction with the British authorities. 
Witbooi, apart from the losses inflicted on him and his people also suffered a grave personal loss. Among the casualties, Witbooi's own young son was also killed in the shooting. Petrus Jefta, one of Witbooi's senior officers, states in an annexure to the English magistrate: ${ }^{295}$

I am one of Hendrik Witbooi's people. I was on Hornkranz on the 12th of April. The captain was there with his people: men, women and children. A while before sunrise, the German soldiers started shooting at us and stormed into the place. There were three groups. When we heard the shooting, we ran out of the houses. We had no chance to resist, but fled. The men came out, but the women had no chance, they got confused with the soldiers. The captain's son, his cousin and three men were shot near the church, when they came out of the captain's house.

The captain's son was first only wounded and ran down to the river, but the soldiers chased him and shot him through the head.

The captain's sister-in-law and his daughter-in-law were shot dead at the same time. Around the captain's house and the church I counted 33 dead women. They were all shot. I saw how some of these women were shot dead by the soldiers.

The German officers were outside while the men inside the village shot the people. They shouted orders and the shooting stopped. They then arrested one of the elders of the church and tied him to the ox wagon.

Two other men and I climbed on a hill and saw the women hiding away. We called them to run away, but they stayed there until the Germans came by. One of the Germans shot one of these women. The others pleaded for their lives and asked the Germans to rather make slaves of them (rather) than to kill them. The soldiers then took them away by pushing them in front of them.

\section{Arms as a means for survival}

Arms and ammunition were a double-edged sword for the Witboois. These arms would be used not only as weapons in case of an attack against them, but were also indispensable not only as a hunting community, but also as warriors and raiders of the cattle and small stock of neighbouring native tribes.

Windhoek was the headquarters of the gun and ammunition traders and the liquor sellers. There were gunpowder and lead and rifles enough: 'skietgoed' was the common name. To allow the gun trade to flourish, there had to be war, and more than one of the traders could have deliberately started hostilities. However, 'skietgoed' was scarce and expensive and could only be paid for with stolen livestock, which further increased the demand for weapons. The later ban by the German Schutztruppe government on arms trade and ammunition with the 'natives' led to great frustration for the Witboois, and possibly many others. 
Hendrik Witbooi himself wrote in his diary about this: ${ }^{296}$

Because of the ban on weapons and ammunition, this war continues. I can never get enough ammunition to tackle a proper battle, as I would. I think differently about weapons than your White people, who have the skill and knowledge to make the necessary and useful things for a comfortable life. But I look at the issue of weapons as follows: guns and ammunition should be free articles for everyone's use. You cannot keep it to yourself and regulate its sales with sanctions. Let weapons be freely available to anyone in the country. We live by the gun, we are hunters, and we need to protect ourselves against our enemies and against wild animals. A man who is alone in the field needs a gun; on every farm, settlement or holding; if only one person is living there, he needs a gun.

Also, God gave the people the skill and knowledge to make weapons as part of his great plan. He made war to punish the sins and injustices of the nations. The sins and injustice of a nation cannot be driven out with a whip, God is perplexing one nation with the help of the neighbor, and firearms are his rod. It is therefore wrong for you to ban firearms. I think firearms should be as freely available as the rain that falls where it wants to fall today, on any ground and on any person, and that cannot be stopped. You are wrong to think stopping firearms will bring peace. It is not a healing plan, not good or right. Someone who wants to ban firearms is like one who withholds another from water.

Witbooi, well versed in the Bible, developed a unique way to interpret war and the accessibility and rules to use rifles and guns - a view perhaps not so far removed from those who still argue for conflict and inflicting harm on others as observed within the Christian, Judaic and Muslim tradition. In short, he advocated both a just war and a just rebellion approach in the political and military lives of people.

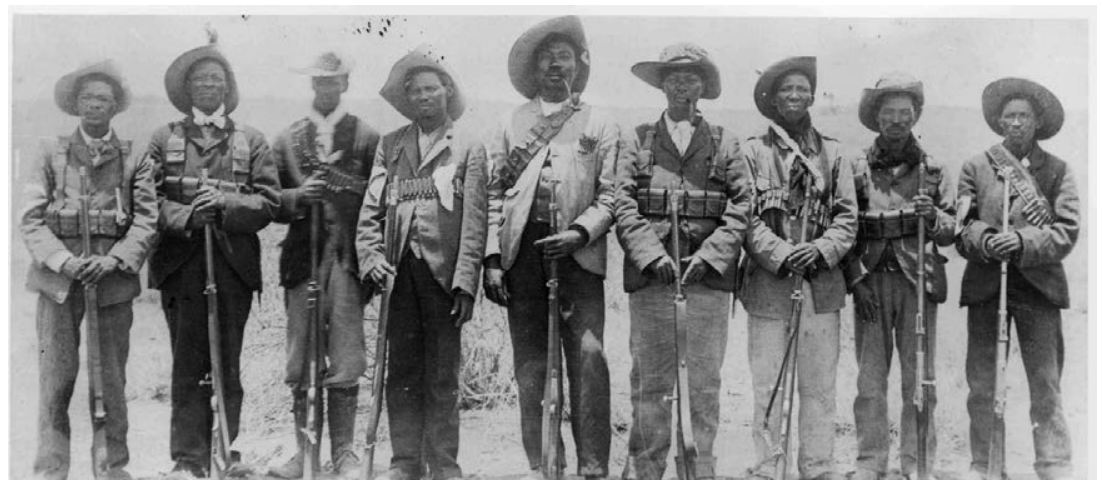

Figure 4: Well-armed Nama warriors photographed at the turn of the century. ${ }^{297}$ 
Horses and guns gave the Witboois a great advantage over the more traditional and conservative native tribes of Namibia, which predominantly used bows and arrows for hunting and for war. Especially the Hereros and the 'Red Nation' (Namas) were Witbooi's biggest target. For example, on one occasion, the dealer, Robert Duncan, and Hendrik Witbooi agreed that Duncan would provide Witbooi with the following ammunition: ${ }^{298}$

- 4 boxes of Martini Henry cartridges

- 4 boxes for the 'rifled guns'

- 4 boxes Westley Richards cartridges

- 1 box paper for Westley Richards cartridges

- 2 boxes of cartridges for Sniders rifles

- 1 box cartridges for the Winchesters

- 100 bags of gunpowder

- 1500 bars of lead

\section{The battlefield at Hornkranz}

During the research done for this article, the researcher, with the help of some farm labourers at the farm Hornkranz, collected as many of the spent cartridge cases he could find on the farmyard. Over a period of two weeks, the researcher and his team collected around 200 cartridge cases of various sorts in total.

The spent cartridge cases were mostly found in the vicinity of the old ruined foundations of an old stone building, which was probably the church building referred to in the declarations. A series of small flat stones, in the shape of gravestones, dot the area around the church. There are no names or markers on this stones.

Identification of the spent cases indicated examples of the following calibres:

Witbooi firearms:

'English' calibres

- Martini-Henry .577 or .450 (41 cases)

- Westley Richards (musket number 1 carbine) .500 or .450 (16 cases)

- Westley Richards (musket number 2) .500 or .450 (45 cases)

- $\quad .577$ Snider (12 caps)

- . 45-75 Winchester, WRA Co centre fire (4 cases)

- . 45-90 Winchester Eley (2 cases)

- Westley Richards Express number 2 577/500 (2 cases)

German firearms:

'German' calibres (German firearms)

- $\quad 11 \mathrm{~mm}$ Mauser () (13 cases)

- 9mm Luger Parabola (DWM)

- $10.6 x 25 \mathrm{~mm}$ R, M1879 or M1883 Straightener (1 case) 
Several of the cartridges bore evidence of exploding. Others have flattened ends, probably because of damage by farm livestock over the years.

There is a whole system of old Witbooi battle ramparts in the hills around the farmyard and above the main water source at the Hornkranz fountain. Here, however, we did not find any cartridge cases. It is clear that the final battle took place directly around the yard and that the Witboois did not occupy the shelters and ramparts to fire or return fire at the German Schutztruppe from high ground, but fired the shots in the settlement and vicinity itself during their flight.

It is evident from the low death rate of German soldiers that the Witboois did not have a chance to utilise their legendary shooting skills properly.

\section{A reconstruction of the battle}

German military records of the battle are scarce. The Schutztruppe Archives at Potsdam were destroyed in an air attack by Allied forces in April 1945 during the Second World War. Most of the records and important historical information were irretrievably lost. ${ }^{299}$

More than a year after the incident (in October 1894), Von Francois reported on the Hornkranz attack in the official German government files regarding military activities of the Colonial Department (Reichskolonialamt). His report refers to his earlier interviews with Witbooi, and gives a generalised motivation for the attack, as well as an indication of the successful outcome of the attack, but the report does not describe the attack in detail. ${ }^{300}$

Captain Schwabe of the German Army, who was a senior lieutenant of the forces under Von Francois, published his memoirs of his time as Schutztruppe officer in Namibia in a 1904 publication where he describes the battle in his perception. ${ }^{301} \mathrm{He}$ admits the killing of women and children, but ascribes this to the confusion stemming from the short distances from which they were firing in the semi-darkness. He puts the total number of Witbooi losses at about 150 people, of whom 60, according to him, were men. He describes the burning huts, human bodies and the remains of animals and discarded rifles. He also mentions the sound of exploding cartridges from the burning huts.

It is difficult to make a convincing reconstruction of the battle from the available archival sources. The most valid contemporary source for this stems from the reports of the Witboois themselves, as indicated above, where it was established that the German soldiers:

- $\quad$ attacked just before first light;

- went right into the sleeping village before opening fire;

- attacked from three sides simultaneously;

- $\quad$ killed indiscriminately;

- $\quad$ fired into the huts; and 
- from Schwabe's report can be added that most of the firing took place at very short distances.

The records do not indicate how many German soldiers were involved in the battle, who their officers were, and by which route or routes they approached the Witbooi encampment, and where they had their temporary base the night before the attack was launched.

Some cartridges were found between the rocks on the fringes of the adjacent sandy and flat small floodplain right next to the Gaub River. This area was then most probably the main area of battle and the place where Captain Hendrik Witbooi and his people had their houses. Several of the cartridge cases had burst open, which correlates with Schwabe's account of exploding cartridges.

From an examination of the battleground and the evidence of spent cartridge cases, it is clear that the Witbooi warriors did not fire from any of the previously prepared battle ramparts, but had to fire on the run, with whatever calibre cartridges they had available. The small number of German calibre cartridges (only 15 cartridges for 88 people killed by German fire) indicates that a sweep was probably undertaken by German soldiers for cartridges after the attack and that they were mostly recovered.

Taking the lay of the terrain and the evidence of cartridge cases into account, the "three sides" from which the German soldiers attacked were, then, probably from the cover of the thickly wooded river bank (mostly sweet-thorn Vachellia karoo and hook-thorn or buffalo thorn Ziziphus mucronata trees), in a sweep upriver as well as downriver. A third contingent must have approached the sleeping Witboois from the cover of the rocks on the riverbanks, making use of the flat, level ground on the eastern side of the river

\section{Aftermath of the attack}

The surviving women and children were taken to a makeshift concentration camp near the old fort (Alte Feste) in Windhoek. The Witbooi warriors fled to the Naukluft Mountains, south of Hornkranz. Here, Hendrik Witbooi, after a long campaign, was forced by Governor Leutwein, Von Francois' successor, to surrender, after which he and his men acted as a commando for the Germans against the Hereros and other rebellious indigenous tribes. It was during this period that he received the Mauser Gewehr 88 carbine, which he is holding in the German archive photographs of the early 1900s. 


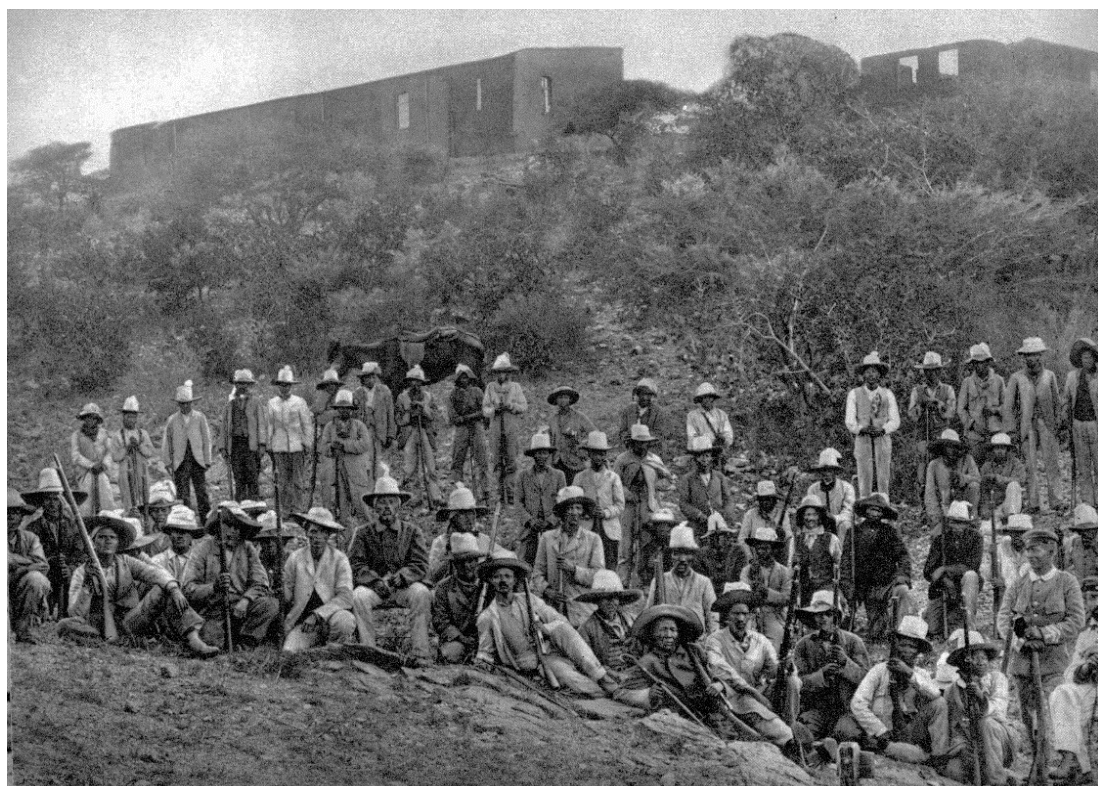

Figure 5: Hendrik Witbooi and his warriors photographed in 1896 after his capitulation. ${ }^{302}$

\section{This is not (yet) the end ...}

Witbooi later, as an old man of almost eighty, took to arms again, after disillusionment with the policies and actions of the German government. A wandering prophet, Baal Stuurman, at the time predicted his eventual victory over the German forces. On 29 October 1905, he and his men attacked an ammunition wagon from the Third Battery under Oberleutnant Stange at Fahlgras. Witbooi was hit in the thigh during the fight by a piece of shrapnel from a mortar bomb and died from blood loss. ${ }^{303}$

His men hastily buried him in a shallow grave and drove back and forth with the horses over the area in order to hide the place of his death to the Germans. Oral tradition reports that it rained immediately after they buried him, obliterating all signs left by the Witbooi soldiers. ${ }^{304}$

His grave was never found. ${ }^{305}$ 


\section{ENDNOTES}

${ }^{275}$ Piet van Rooyen is Professor (emeritus) at the School of Military Science of the University of Namibia. The author would like to thank Prof (emeritus) Andre du Pisani for archival assistance and obtaining the necessary permission to reproduce photographic material from the National Archives of Namibia.

${ }^{276}$ TW Gevers. "The geology of the Windhoek District in Southwest Africa". Transactions of the Geological Society of South Africa 1934. 223-225.

${ }^{277}$ H Witbooi. Die dagboek van Hendrik Witbooi. Cape Town: The Van Riebeeck Society, 1939.

${ }^{278}$ T Leutwein. Elf Jahre Gouverneur in Deutsch-Südwestafrika. Reprint. Windhoek: Namibia Scientific Society, 1997.

${ }^{279}$ See P van Rooyen. "Patroondoppies vertel die verhaal van die Hornkranz-slagveld". Wild \& Jag/Game \& Hunt March 2018. 58-62.

${ }^{280}$ B Lau. Namibia in Jonker Afrikaner's time. Windhoek: National Archives of Namibia, 1987, $41-46$.

${ }^{281}$ M Wallace. A history of Namibia: From the beginning to 1990. New York, NY: Columbia University Press, 2011, 115.

${ }^{282}$ M Legassick. "The Northern Frontier to 1820: The emergence of the Griqua people". In R Elpick \& H Giliomee (eds), The shaping of South African society. Cape Town, Longman, 1979, 247.

${ }^{283}$ B Lau. The Hendrik Witbooi papers. Windhoek: National Archives of Namibia, 1995, vi.

${ }^{284}$ Wallace op. cit., pp. 115-121.

${ }^{285}$ Ibid., p. 118.

${ }^{286}$ Ibid., p. 120.

${ }^{287}$ Ibid.

${ }^{288}$ Ibid., p. 124.

${ }^{289}$ National Archives of Namibia. Image Number 02009 - German Schutztruppe with "88" Mauser rifles in Windhoek. Photo reproduced with permission of the National Archives of Namibia.

${ }^{290}$ Records, Auswärtiges Amt, Kolonial-Abteilung, R 1001/1486 Bundesarchiv Berlin.

${ }^{291}$ Paraphrased from Lau, The Hendrik Witbooi Papers op. cit., pp. 126-127.

${ }^{292}$ National Archives of Namibia. Image Number 0041, Series 4 - Hendrik Witbooi seated, with gun. Photo reproduced with permission of the National Archives of Namibia.

${ }^{293}$ Lau, The Hendrik Witbooi Papers op. cit., pp. 128-130.

${ }^{294}$ Author's private photo collection.

${ }^{295}$ Lau, The Hendrik Witbooi Papers op. cit., pp. 209-210.

${ }^{296}$ Witbooi op. cit., p. 135.

${ }^{297}$ National Archives of Namibia. Image Number 27041 - Jacob Marengo and eight of his followers, standing with guns. Photo reproduced with permission of the National Archives of Namibia.

${ }^{298}$ Lau, The Hendrik Witbooi Papers op. cit., p. 44.

${ }^{299}$ Deutsche Digitale Bibliothek. "Kaiserliche Schutztruppen (Bestand)". Archivportal. 2021. $<\underline{\text { https://www.archivportal-d.de/item/RPV5CWC34C4LR7FPEI6SVS6W5G5DW- }}$ MUO $>$ Accessed on 26 March 2021.

${ }^{300}$ Records, Auswärtiges Amt op. cit.

${ }^{301} \mathrm{~K}$ Schwabe. Mit Schwert und Pflug in Deutsch-Südwestafrika: Vier Kriegs- und Wanderjahre. $2^{\text {nd }}$ ed. Berlin: Mittler und Sohn, 1904; see J Silvester \& J-B Gewald. Words cannot be found: German colonial rule in Namibia: An annotated reprint of the 1918 Blue Book. Sources for African History, vol. 1. Leiden: Brill, 2003. 
${ }^{302}$ National Archives of Namibia. Image Number 27187 - Hendrik Witbooi and his soldiers. Photo reproduced with permission of the National Archives of Namibia.

${ }^{303} \mathrm{H}$ Drechsler. Let us die fighting: The struggle of the Herero and Nama against German imperialism (1884-1915). Berlin: Akademie-Verlag, 1966.

${ }^{304} \mathrm{P}$ van Rooyen. Personal interview with Captain Christian Rooi, acting Witbooi traditional leader, Gibeon, 2002.

${ }^{305}$ See P van Rooyen. Op soek na Witbooi. Windhoek: Macmillan, 2002. 